Valentine, R. C. \& Bradieleld, J. R. G. (1954). J. gen. Microbiol. 11, 349-357.

\title{
The Urea Method for Bacterial Viability Counts with the Electron Microscope and its Relation to other Viability Counting Methods
}

\author{
By R. C. VALENTINE and J. R. G. BRADFIELD \\ Cavendish Laboratory, University of Cambridge
}

SUMMARY : Live rod-shaped bacteria incubated on a medium containing $3 \%$ urea grow but do not divide. They thus become much longer than dead bacteria lying among them, and the numbers of each kind can easily be counted in an electron microscope. This urea method gives accurate results and has several advantages over colony-counting methods. The significance of various interesting differences in the counts given by the two methods is discussed. Slope cultures at $18 \mathrm{hr}$. gave live counts of over $95 \%$ by the urea method.

A common need in quantitative bacteriology is to discover what proportion of bacteria in a given sample is alive. The standard procedure is to make counts of the colonies which form when measured volumes of the sample, suitably diluted, are incubated in nutrient media. On the assumption that each colony arises from one live bacterium, the number of the latter in the sample can then be determined. Such counts made before and after some treatment will enable the resulting fall in viability to be measured. In order to find the actual percentage of live cells in a sample a total count of the bacteria in the measured volume must also be made. In studying the survival of bacteria during drying from tiny droplets or thin films, an accurate measurement of the volume of the samples becomes difficult or impossible. To overcome this problem a new method has been developed for determining the proportion of live bacteria in such tiny samples. This paper gives details of the method and typical results of a test of its accuracy.

The method is based on the property possessed by urea in concentrations of about $3 \%(0.5 \mathrm{M})$ of preventing the division of certain bacteria without inhibiting their growth (Wilson, 1906). Hence after incubation of suitable bacteria for a few hours on nutrient agar containing urea, the live cells have grown into giant forms which can readily be distinguished from the shorter dead organisms (Pl. 1, fig. 5). The numbers of live and dead can then easily be counted in an electron microscope.

\section{EXPERIMENTAL}

The action of urea

We have no information about the mechanism by which urea exerts its effect. We have, however, investigated its action on the growth of a paracolon bacillus over a range of concentrations of urea from 1 to $10 \%$ in nutrient agar medium. The bacteria were taken from $18 \mathrm{hr}$. slope cultures, suspended in broth, and grown on filmed electron microscope specimen grids as described below. 
In the presence of $1 \%$ urea, there was extensive growth with the formation of colonies (Pl. 1, fig. 2), but no giant long forms. Between 1 and $2 \%$ urea, varying proportions of long forms and colonies were produced. With a urea concentration of $3 \%$, up to as many as $99.5 \%$ of the bacteria grew into long forms (Pl. 1, figs. 3, 4) and no colonies were formed. Concentrations of urea above $4 \%$ produced increasing numbers of bacteria showing neither growth nor division.

Various other agencies for producing long forms were also investigated (lithium salts; ultraviolet and $\mathbf{X}$-irradiation), but none of these was found as satisfactory as urea for producing, as nearly as possible, complete inhibition of division while permitting every live organism to grow.

\section{Description of the method}

The medium. A volume of $20 \mathrm{ml}$. of melted nutrient agar (Difco) is poured into a Petri dish containing $0 \cdot 6 \mathrm{~g}$. urea, gently rocked to ensure thorough mixing, and then left to set. Care must be taken to avoid contamination of the medium, but it is inadvisable to attempt heat sterilization of the urea agar as there is risk of decomposition of urea with the formation of ammonia.

Choice of bacteria. A species suitable for counting by the urea method must conform to the following requirements: (1) it must grow without cell division on the urea medium; (2) long filamentous forms must not occur normally; (3) it must be capable of appreciable growth in a few hours.

A convenient organism which we have used extensively for the 'urea count' is the paracolon bacillus 'D.201 H', used by Fry \& Greaves (1951). On an $18 \mathrm{hr}$. nutrient agar slope this exists as a short rod (1-3 $\mu$. long) often appearing almost spherical in shape (Pl. 1, fig. 1). But when cultivated on the urea medium the short rods rapidly form filaments (Pl. 1, figs. 3, 4) which may grow to $150 \mu$. in length. The following organisms have also been tested and all were found suitable for urea counts: Escherichia coli (ten untyped strains), Serratia marcescens (Chromobacterium prodigiosum), Salmonella paratyphi-C (Pl. 2, fig. 7), Proteus morganii (Pl. 2, fig. 8). All of these produced on urea agar long forms which were easily distinguishable from the normal cells in each case. The long forms of $\boldsymbol{P}$. morganii developed despite the appreciable urease activity possessed by this organism (Bergey's Manual, 1948; Ishikawa, 1928), probably because the bulk of medium was so great compared with that of the bacteria. Cocci, however, do not grow long.

The grids. Stainless steel electron microscope specimen grids (R.C.A. Photophone Ltd., 36, Woodstock Grove, London W. 12) were used. Those made of copper or silver may prove toxic on the urea medium. After being well washed in distilled water, the grids were covered with a thin nitrocellulose film (Cosslett, 1951). A drop (0.01 ml.) of $1 \%(w / v)$ nitrocellulose in amyl acetate solution spread on a clean water surface about $50 \mathrm{~cm} .{ }^{2}$ in area produces a film of suitable thickness. Too thick a film impedes the diffusion of nutrients during the subsequent incubation of the bacteria on the urea agar; too thin a film tears very easily.

Procedure. Each grid is placed film-side downwards on the medium and a 
small loopful of the bacterial suspension under investigation is placed centrally upon it, so that the drop covers about two-thirds of the surface of the grid. The bacteria are thus separated from the medium by the film of nitrocellulose (Fig. 1). However, a film prepared as described will allow nutrient material to pass through to the cells (Hillier, Knaysi \& Baker, 1948; Brieger \& Cosslett, 1949). The dish is then incubated at $37^{\circ}$ for a sufficient time to allow all the live bacteria to grow long. With an active suspension this is usually about $3 \mathrm{hr}$. (Pl. 1, fig. 5), but the time required will be longer when some of the cells, though live, have an increased lag phase because of previous treatment such as drying or irradiation. A suitable time must be found for each experiment, but it should not be longer than $c .6 \mathrm{hr}$., as some lysis will then occur, making the count more difficult.

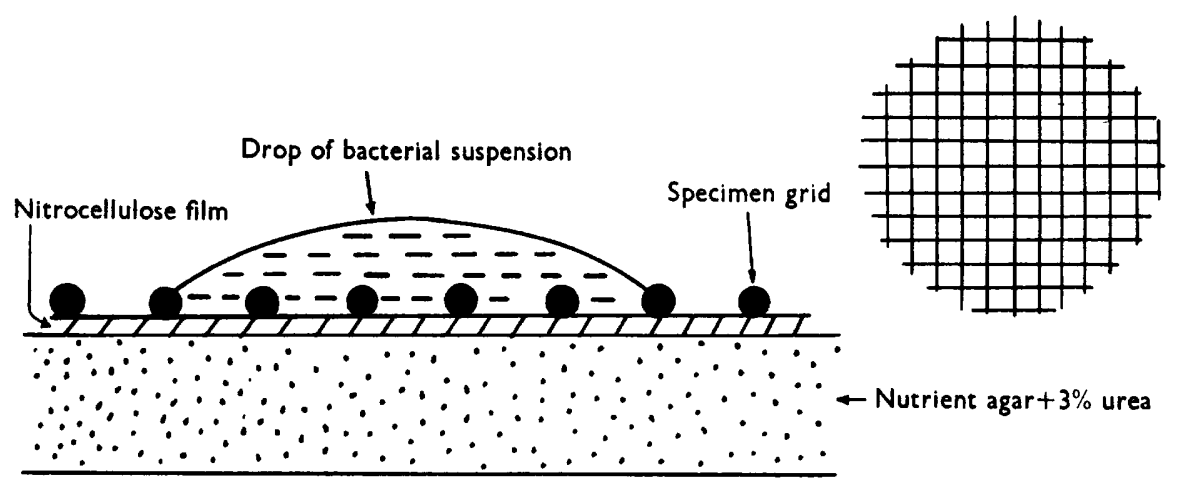

Fig. 1. Diagram (not to scale) showing the incubation of a drop of bacterial suspension on an electron microscope specimen grid placed on the urea agar medium. On the right is a smaller plan view of the grid alone. The actual grids used contain more squares than shown in the diagrams. The grids are $2 \mathrm{~mm}$. in diameter, with bars $70 \mu$. apart (centre to centre).

After incubation, the bacteria are fixed by inverting the dish over a few drops of formalin or $1 \%$ osmium tetroxide solution for $5 \mathrm{~min}$. The grids are then removed from the medium by running a little distilled water round each from a pipette and allowing them to float off. They are then floated, still filmside downwards, on the surface of distilled water and left overnight. All traces of medium diffuse away leaving very little contaminating material round the bacteria lying on the film. The grids are lifted off the water, lightly blotted at the edge, and allowed to dry completely lying film upwards on filter paper. (The films will tear if they dry in contact with a surface.) The grids are then ready for examination in the electron microscope; there is no need for metal shadowing.

Counting. For accurate counting it is desirable to have available a direct magnification of about $\mathbf{4 0 0 0}$ times; below this it is often difficult to distinguish dead bacteria from particles of detritus. We have thus found it essential to use an electron microscope. This also greatly decreases the strain of protracted counting on large numbers of samples. Moreover, empty cell membranes are 
easily detected in the electron microscope (Pl. 1, figs. $5 b, 6)$ so that the lysed cells which commonly result during killing experiments are not overlooked. For the magnifications involved, the simplest models of electron microscope are adequate and handling and alignment are very easy.

A grid of ungrown bacteria is first examined in the electron microscope and the size of the longest normally occurring cell is noted by reference to a simple scale scratched on the fluorescent screen. All those bacteria incubated on the urea medium which have grown longer than this are counted as live. The short ones which have shown no signs of growth are reckoned as dead. When the grid has been incubated for a sufficient time, there is a very clear distinction between the long and the short forms (Pl. 1, fig. 5). This has been confirmed by plotting length distribution curves. When it is necessary to incubate for longer than usual, to allow cells with an increased lag phase to grow, some of the bacteria may be very long and entangled ( $\mathrm{Pl}$. 1, fig. 4). In such cases it is easier to count the ends of the long forms and divide by two than to count individual long bacteria. Where ends are counted, one must also count places where a long bacterium meets a grid bar, except where it obviously curls back into the square. Various minor errors may occur (long bacteria surmounting a grid bar so as to lie in two squares; small bacteria hidden beneath the overhanging edge of a grid bar), but the accuracy which can be achieved (see below) indicates that such errors are very small.

The number of cells which must be counted depends on the precision which is desired in the estimate of the percentage of live cells. The standard error of this percentage is inversely proportional to the square root of the number of bacteria counted (provided there is a random distribution of live and dead cells) and is given by the expression

$$
\sigma= \pm \sqrt{ }\left[\frac{L}{n}(100-L)\right] \%
$$

where $L$ is the estimated percentage of live cells, $n=$ the number of cells counted, and $\sigma$ is the standard error of the percentage $L$.

Thus with a survival of $50 \%$, the standard error with a count of 400 cells will be $\pm 2 \frac{1}{2} \%$. This therefore will be usually a sufficient number to count on each grid, and if the original drop of bacterial suspension was of a suitable concentration (about $10^{7}-10^{8}$ bacteria $/ \mathrm{ml}$.) the count can be quickly made. We usually count about 400 cells on each of three grids prepared from the same suspension and total the results obtained.

\section{Tests on the validity of the method}

The validity of the urea method of counting was tested by using it to determine the live count of bacterial suspensions containing known percentages of heat-killed bacteria.

An $18 \mathrm{hr}$. agar slope growth of a paracolon bacillus (D. $201 \mathrm{H}$ ) was suspended in broth (about $10^{7}$ bacteria/ml.). A few ml. of this suspension were then held at $70^{\circ}$ for $5 \mathrm{~min}$. After cooling, the heat-killed suspension was mixed in various proportions with the unheated suspension to give samples containing 100, 75, 
$50,25,12 \frac{1}{2}$ and $0 \%$ unheated bacteria. (These cannot be taken as exactly the concentrations of live bacteria since the unheated suspension contains some dead cells-see discussion.) Counts were then made by the urea method as described above, three grids being prepared and counted from each suspension. The results are shown in Table 1. The last column gives the counts of long (i.e. 'live') bacteria as percentages of the live count on the unheated cells, and these agree well with the percentages of unheated cells in the suspension.

\section{Table 1. Results of a test on the accuracy of the urea method}

Counts of live cells in bacterial suspensions prepared by mixing known proportions of heat-killed and unheated organisms; paracolon bacillus D. $201 \mathrm{H}$.

\begin{tabular}{|c|c|c|c|c|c|}
\hline $\begin{array}{l}\text { Unheated cells } \\
\text { in sample } \\
(\%)\end{array}$ & Grid no. & $\begin{array}{l}\text { Total no. } \\
\text { of bacteria } \\
\text { counted }\end{array}$ & $\begin{array}{c}\text { Count of long } \\
(=\text { live }) \\
\text { bacteria } \\
(\%)\end{array}$ & $\begin{array}{c}\text { Standard error } \\
\text { expected in } \\
\text { sample } \\
(\%)\end{array}$ & $\begin{array}{c}\text { Count as } \% \\
\text { of count } \\
\text { on } 100 \% \\
\text { unheated cells* } \\
(\%)\end{array}$ \\
\hline 100 & $\begin{array}{c}\mathbf{1} \\
\mathbf{2} \\
\mathbf{3} \\
\text { Total }\end{array}$ & $\begin{array}{r}400 \\
450 \\
300 \\
1150\end{array}$ & $\begin{array}{l}98 \cdot 5 \\
98 \cdot 7 \\
98 \cdot 0 \\
98 \cdot 4\end{array}$ & $\begin{array}{l} \pm 0.6 \\
\pm 0.5 \\
\pm 0.8 \\
\pm 0.4\end{array}$ & $\frac{-}{100}$ \\
\hline 75 & $\begin{array}{c}4 \\
5 \\
6 \\
\text { Total }\end{array}$ & $\begin{array}{r}890 \\
883 \\
923 \\
2696\end{array}$ & $\begin{array}{l}74 \cdot 1 \\
72 \cdot 0 \\
71 \cdot 7 \\
72 \cdot 7\end{array}$ & $\begin{array}{l} \pm 1.5 \\
\pm 1.5 \\
\pm 1.5 \\
\pm 0.9\end{array}$ & $\begin{array}{l}75 \cdot 4 \\
73 \cdot 2 \\
72 \cdot 9 \\
73 \cdot 9\end{array}$ \\
\hline 50 & $\begin{array}{c}7 \\
8 \\
9 \\
\text { Total }\end{array}$ & $\begin{array}{c}\text { (Film torn) } \\
637 \\
603 \\
1240\end{array}$ & $\begin{array}{l}48 \cdot 5 \\
48 \cdot 5 \\
48 \cdot 5\end{array}$ & $\begin{array}{l} \pm 2 \cdot 0 \\
\pm 2 \cdot 0 \\
\pm 1 \cdot 4\end{array}$ & $\begin{array}{l}49 \cdot 3 \\
49 \cdot 3 \\
49 \cdot 3\end{array}$ \\
\hline 25 & $\begin{array}{c}10 \\
11 \\
12 \\
\text { Total }\end{array}$ & $\begin{array}{c}\text { (Film torn) } \\
\text { 365 } \\
407 \\
772\end{array}$ & $\begin{array}{l}24 \cdot 4 \\
23 \cdot 3 \\
23 \cdot 8\end{array}$ & $\begin{array}{l} \pm 2 \cdot 3 \\
\pm 2 \cdot 1 \\
\pm 1 \cdot 5\end{array}$ & $\begin{array}{l}24 \cdot 8 \\
23 \cdot 7 \\
24 \cdot 2\end{array}$ \\
\hline $12 \frac{1}{2}$ & $\begin{array}{c}13 \\
14 \\
15 \\
\text { Total }\end{array}$ & $\begin{array}{r}78 \\
143 \\
410 \\
631\end{array}$ & $\begin{array}{l}16 \cdot 7 \\
13 \cdot 3 \\
12 \cdot 4 \\
13 \cdot 1\end{array}$ & $\begin{array}{l} \pm 4 \cdot 2 \\
\pm 2 \cdot 8 \\
\pm 1 \cdot 6 \\
\pm 1 \cdot 3\end{array}$ & $\begin{array}{l}17 \cdot 0 \\
13 \cdot 5 \\
12 \cdot 6 \\
13 \cdot 3\end{array}$ \\
\hline 0 & & No liv & bacteria & & \\
\hline
\end{tabular}

* Obtained by increasing the actual live count (column 4) by a factor 100/98.4 in order to take account of the fact that the $100 \%$ unheated cells gave a live count of only $98.4 \%$.

\section{DISCUSSION}

Advantages and disadvantages of the method. The urea method provides a simple and convenient way of discovering the viability of a bacterial suspension and has a number of advantages over other procedures.

(1) The count is unaffected by clumping of the cells. When a colony count is used to determine the viability it has to be assumed that each colony arises from a single cell, and clumping of the organisms may vitiate the count. That a considerable amount of clumping does exist even in young cultures of Escherichia coli after shaking (Jennison, 1937) is a fact that is often overlooked. It is hard to avoid and may be a source of serious error in the usual counting methods. Lea (1946) pointed out that the controversial departures from an 
exponential fall in the number of survivors during irradiation may be due to errors in the count as a result of clumping. Migaki \& McCulloch (1949), who worked with bacteria treated with surface-active agents, also found the colony-counting method unsatisfactory because of clumping.

(2) Since only a very small unmeasured volume of culture (very approximately $10^{-4} \mathrm{ml}$./grid) is needed for the count, experiments can be carried out on the survival of bacteria in droplets and films, which have not been possible before. In nature, bacteria are normally carried in these conditions and the results of such experiments should be more relevant than similar ones performed on bulk suspensions.

(3) It is a simple matter to examine the morphology of the bacteria with the electron microscope while the counts are being made. The short (i.e. 'dead') bacteria may differ in appearance from the normal organisms and hence make it possible to associate morphological changes with death.

(4) The urea method is at present the only simple procedure for discovering directly what percentage of the bacteria in a culture are alive. The colony count gives the number of viable cells/unit volume of suspension and the percentage viability can then be deduced only if a total count is made.

The main limitations of the method have already been noted. It can be applied only to certain bacteria (in particular it is not suitable for cocci), and it requires that the live bacteria shall be capable of showing growth within c. $6 \mathrm{hr}$. The urea method assumes rather different definitions of 'live' and 'dead' bacteria from those adopted in making a colony count, and it may not therefore be suitable for work where the main interest centres on the ability of cells to multiply. This point is further discussed below.

The meaning of 'live' and 'dead' bacteria. In making a colony count, a cell is counted as 'live' only if it can multiply to form a visible colony of bacteria, whereas in the urea method a bacterium, to be reckoned as 'live', is required only to be capable of some growth on the medium. It has been found that there are marked differences between counts made by the two methods on suspensions of bacteria irradiated with X-rays or with ultraviolet light. These differences result from the presence after irradiation of bacteria capable of growth but not of repeated division, which will thus be counted as 'dead' by the colony count and 'live' by the urea method. Such bacteria are also known to exist in cultures treated with antibiotics. It is perhaps best to use the word 'viable' to describe cells which can multiply to form a colony, and the word 'live' more broadly for those which can grow (or show other signs of life such as respiration) even if unable to go on dividing. In many cases, however (e.g. counts on natural untreated populations of bacteria) there is no reason to expect significant numbers of bacteria to be capable of growth but not of division. In these cases colony-counting methods and the urea method are, in principle at least, of equal merit, but the latter is probably more accurate because of the great difficulty of avoiding clumping in the colony-counting method. But, if there is a significant difference between the two counts (clumping having been avoided), and if only those bacteria which can multiply are of interest, then the colony count is the more relevant-though it must be 
remembered that some of the 'dead' cells may not irreversibly have lost their ability to divide (Heinmets, Taylor \& Lehman, 1954). In general it is clearly desirable to make, in appropriate cases, both kinds of count and to compare the results. For instance, in studying the effects of external factors on bacterial cells it is important to distinguish between effects on the systems responsible for producing new protoplasm and effects on the systems involved only in cell division. Comparisons between urea counts (depending on growth alone) and colony counts (depending on both growth and division) enable precisely such a distinction to be made. Moreover, the differences often observed between the results of the two counts confirm the concept, suggested by restoration experiments, that many cells found to be non-viable by colony counts are in other senses still live and can be restored by suitable treatment to full viability (Heinmets et al. 1954). The need which these authors indicated for a method of measuring degrees of 'complete' sterility may in fact be met by the urea method.

The percentage viabilities of untreated bacterial cultures. The results given in column 4 of Table 1 , which show an average of $98.4 \%$ live cells in suspensions containing $100 \%$ unheated cells, have direct bearing on the question of what proportion of the cells in an actively growing culture is alive. Differing views have been put forward on this point. By comparing the viable count given by the colony counting method with a direct microscopic count of the total number of bacteria, several workers (Wilson, 1922, 1926; Régnier, David \& Kaplan, 1932; Jordan \& Jacobs, 1944) concluded that usually only about $70-90 \%$ of the organisms are viable even during the logarithmic phase of growth. This is further discussed in Topley and Wilson (1946). Kelly \& Rahn (1932) found by microscopic observation that, under favourable conditions, all the cells in a culture appeared to divide. Ziegler \& Halvorson (1935) stated that when great care was taken to break up clumps of bacteria the colony count and direct count gave the same result. Jennison (1937) concluded that the reported differences between the two counts could be wholly explained by clumping of cells. After measuring and correcting for this he reported that cultures of Escherichia coli were practically $100 \%$ viable.

By using the urea method we have consistently found that 95-100\% of the bacteria taken from $18 \mathrm{hr}$. agar slope cultures of the paracolon bacillus used and of Escherichia coli were live. This observation would not be incompatible with the former viewpoint if there were numbers of cells on the slope cultures capable of growth and perhaps a few divisions but, as a result of some disturbance of their division mechanism, incapable of continuing to grow and divide to form a visible colony. However, there is no reason to expect this, and we think it much more probable that the differences between viable counts and total counts have been due to clumping of cells. Thus it may be that, in some cases at least, the viability of an agar slope culture is really much nearer $100 \%$ than colony counts, in conjunction with total counts, have suggested. This would confirm the point made by Hinshelwood (1946) that the close approximation found in practice to a logarithmic growth law suggests that mortality under favourable conditions is low. 
We are much indebted to Dr R. M. Fry for supplying us with a culture of the paracolon bacillus (D. $201 \mathrm{H}$ ) used by Fry \& Greaves (1951); also to the Agricultural Research Council for support during this work.

\section{REFERENCES}

Bergey's Manual of Determinative Bacteriology, 6th ed. (1948), p. 486. Edited by Breed, R. S., Murray, E. G. D. \& Hrtchens, A. P. Baltimore: Williams and Wilkins.

Brieger, E. M. \& Cosslett, V. E. (1949). Preparation of bacteria for electron microscopy. Nature, Lond. 164, 352.

Cosslett, V. E. (1951). Practical Electron Microscopy, p. 185. London: Butterworth's Scientific Publications.

Fry, R. M. \& Greaves, R. I. N. (1951). The survival of bacteria during and after drying. J. Hyg., Camb. 49, 220.

Heinmets, F., Taylor, W. W. \& Lehman, J. J. (1954). The use of metabolites in the restoration of the viability of heat and chemically inactivated Escherichia coli. J. Bact. 67, 5.

Hillier, J., KNaysi, G. \& Baker, R. F. (1948). New preparation techniques for the electron microscopy of bacteria. J. Bact. 56, 569 .

Hinshelwood, C. N. (1946). The Chemical Kinetics of the Bacterial Cell, p. 64. Oxford: Clarendon Press.

IsHIKAWA, M. (1928). Influence of carbohydrates on bacterial decomposition of urea. J. infect. Dis. 43, 67.

Jennison, M. W. (1937). Relations between plate counts and direct microscopic counts of Escherichia coli during the logarithmic growth period. J. Bact. 33, 461.

JoRDAN, R. C. \& JACOBS, S. E. (1944). The growth of bacteria with a constant food supply. 1. Preliminary observations on Bacterium coli. J. Bact. 48, 579.

Kelly, C. D. \& RAHN, O. (1932). The growth rate of individual cells. J. Bact. 23, 147.

LeA, D. E. (1946). Actions of Radiations on Living Cells, pp. 78, 319. Cambridge University Press.

MigakI, H. \& McCulloch, E. C. (1949). Survivor curves of bacteria exposed to surface-active agents. J. Bact. $58,161$.

RÉgnier, J., David, R. \& Kaplan, A. (1932). Contribution à l'étude numérique de la multiplication microbienne. De l'existence de la phase de latence. C.R. Acad. Sci., Paris, 194, 323.

Topley and Wilson's Principles of Bacteriology and Immunity, 3rd ed. (1946), p. 88. Revised by Wilson, G. S. \& Miles, A. A. London: Edward Arnold.

Wilson, G. S. (1922). The proportion of viable bacteria in young cultures, with special reference to the technique employed in counting. J. Bact. 7, 405 .

WiLson, G. S. (1926). The proportion of viable bacteria in agar cultures of B. aertrycke (mutton), with special reference to the change in size of the organism during growth, and in the opacity to which they give rise. J. Hyg., Camb. 25, 150.

Wilson, W. J. (1906). Pleomorphism, as exhibited by bacteria grown on media containing urea. J. Path. Bact. 11, 394.

Ziegler, N. R. \& Halvorson, H. O. (1935). Application of statistics to problems in bacteriology. IV. Experimental comparison of the dilution method, the plate count, and the direct count for the determination of bacterial populations. J. Bact. 29, 609. 
Journal of General Microbiology, Vol. 11, No. 3

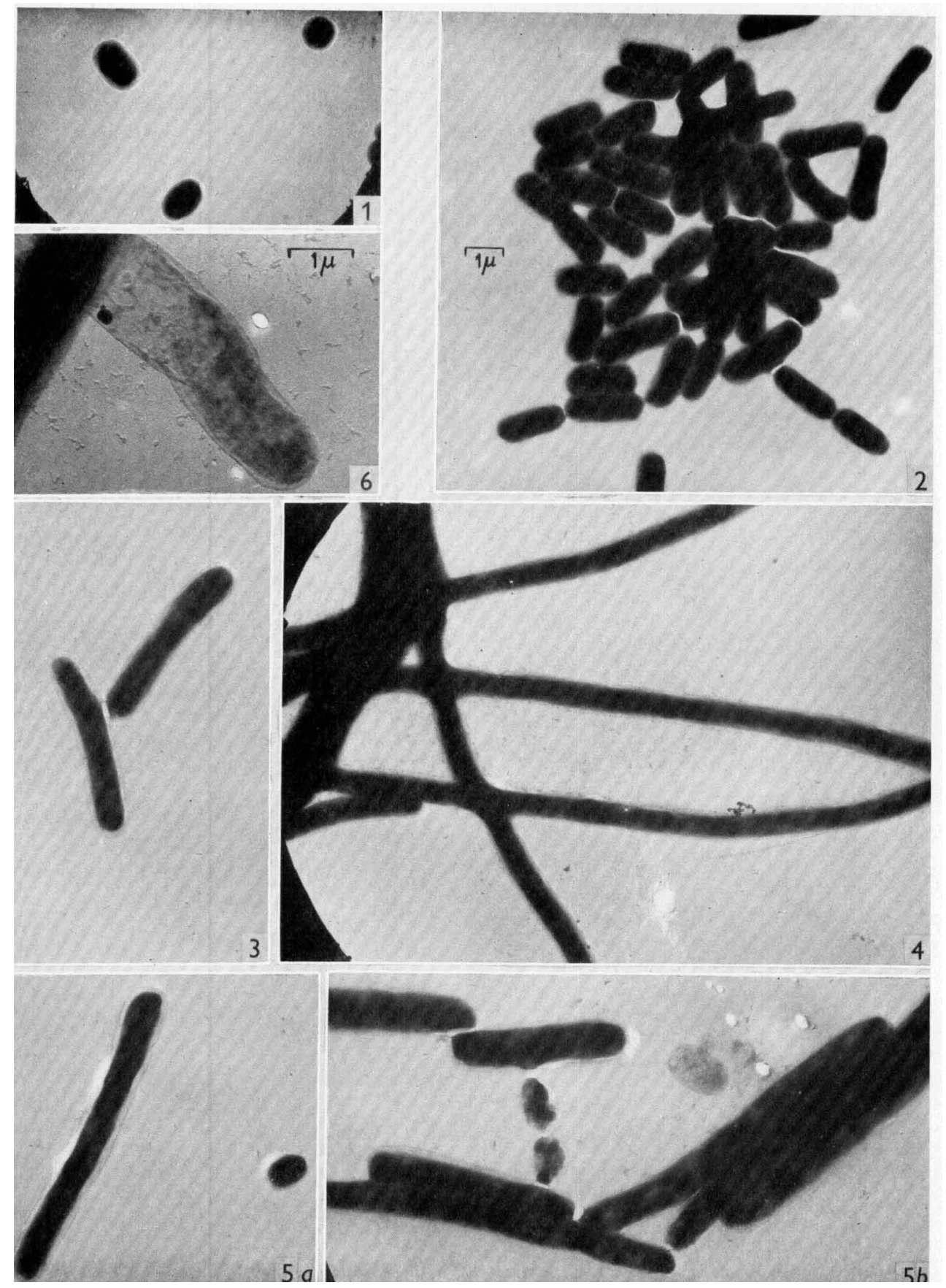

R. C. Valentine \& J. R. G. Bradfield-Urea method for counting live bacteria. Plate 1 
Journal of General Microbiology, Vol. 11, No. 3
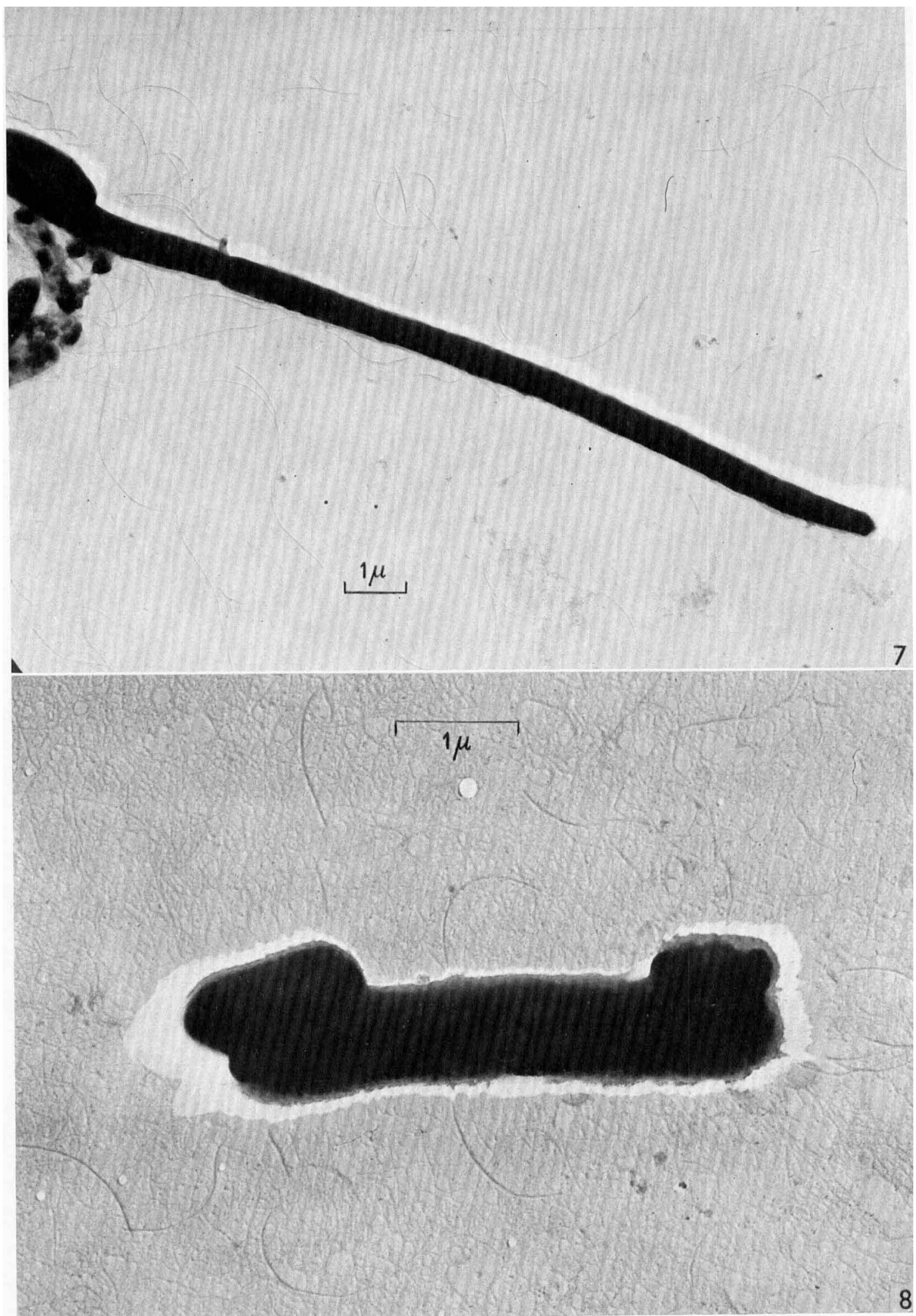

R. C. Valentine \& J. R. G. Bradfield-Unea method for counting live bacteria. Plate 2 


\section{EXPLANATION OF PLATES}

\section{Plate 1}

The magnification of figs. 1 to 5 is $\times 5200$, shown by a scale equivalent to $1 \mu$. on Fig. 2 . The magnification of fig. 6 is $\times 8800$, also shown by a $1 \mu$. scale.

Fig. 1. Paracolon bacilli (D. $201 \mathrm{H}$ ) taken from an $18 \mathrm{hr}$. agar slope. Cells in resting phase; few longer than $1.5 \mu$.

Fig. 2. A microcolony formed by $3.5 \mathrm{hr}$. incubation of bacilli like those shown in fig. 1 grown directly on an electron microscope specimen grid placed on nutrient agar containing $1 \%$ urea. Cells $1 \cdot 5-2 \cdot 3 \mu$. long.

Fig. 3. The bacilli after incubation for $2.5 \mathrm{hr}$. on a grid placed on nutrient agar containing $3 \%$ urea. Cells $4-6 \mu$. long.

Fig. 4. As for fig. 3, but after $6 \mathrm{hr}$. incubation. Cells 30-50 $\mu$. long.

Fig. 5. Appearance of the bacilli taken from a partly killed culture after $3 \mathrm{hr}$. incubation on $3 \%$ urea agar. The live cells have grown long and are easily distinguishable from the shorter dead cells. $5 a$, one giant (live) cell and one normal sized (dead) cell. $5 b$, seven giant (live) cells and three normal sized (dead) cells, one of which has lysed.

Fig. 6. Part of a lysed giant cell.

\section{Plate 2}

Fig. 7. Salmonella paratyphi-C after $5 \mathrm{hr}$. incubation on $3 \%$ urea agar. One giant (live) organism $16 \mu$. long and a clump of normal sized (dead) cells of lengths up to $2 \mu$., most of which have lysed and contain dense bodies. $\times 9500$ shown by the $1 \mu$. scale.

Fig. 8. Proteus morganii after $5 \mathrm{hr}$. incubation on $3 \%$ urea agar, showing one long (live) cell of length $4.5 \mu$. beside two normal sized (dead) cells 1.5 and $1.0 \mu$. long. The length of the longest cell found on ordinary nutrient agar is $2 \cdot 0 \mu . \times 18,800$ shown by the $1 \mu$. scale.

(Received 13 April 1954) 